\title{
What Can We Learn About Feminism from Web Portals? - Analysing Media Bulletins
}

\author{
Mirjana Adamović, Institute for Social Research, Zagreb, Croatia
}

\section{Introduction}

ociety's relationship to feminism and feminist values speaks not only about the level of gender equality achieved but also the level of the democracy achieved and readiness to support the equality of those who believe their rights are being violated and feel like they are not full members of that society. Women, to paraphrase Carole Pateman (1988) are still not, nor ever have been, recognised as equal members or citizens of any known democracy because, even though they have a general right to vote, in public spaces of political or economic importance where decisions of crucial social importance are being made, women continue to not be present or underrepresented despite the best efforts of gender mainstreaming. Moreover, women are marginalised in the public sphere (Harp et al., 2016) as well as marginalised and underrepresented in media discourses and practices (Bachmann, Harp \& Locke, 2018; Byerly \& Ross, 2006). Basically, stereotyping feminism and feminists is inseparable from stereotyping women in general.

The new kind of antifeminism differs from the form which appeared in the 1970 s and 1980 s, despite individual feminist values being incorporated in institutional and social lives, namely "a substitute for feminism" as explained by Angela McRobbie (2009), in the still patriarchal system of economic power and domination, is a new form of the "sexual contract", promising young women that they will achieve equality through education and employment and by participating in the consumer culture and civil society. 


\section{Media, Women and Feminism}

The media is a "major cultural and ideological force standing in a dominant position with respect to the way in which social relations and political problems are defined and the production and transformation of popular ideologies in the audience addressed" (Hall, 1988, p. II8). Institutions such as the family, schools and media produce and reproduce hegemonic ideologies whereby the mainstream media adapt ideologies to "common-sense" attitudes (Vavrus, 2002).

Backmann et al. (2018) believe there are several landmark moments in the history of researching the relationship between women and the media. One of the first is the conclusion reached by the sociologist Gaye Tuchman (1978) that women mostly do not feature in the mediated public sphere or are featured as carriers of stereotypical roles of victims, mothers or incompetents, and that the issues of gender equality as well as women's questions and issues are not of significant interest to the media. She calls this state "'symbolic annihilation' because by watching women's representation in the media children can't conclude anything other than the woman belongs at home" (cf. Lance \& Paschyn, 2018). The following landmark moment was the work of Laura Mulvey (1975) which speaks about "women as the object of the male gaze" in movies, where women are most often featured in a passive role or one unimportant for the screenplay, and mostly serve as the object of erotic desire of both movie characters and the audience (see Albertson, 2018, p. 54). Another landmark moment in media research was the realisation that female identity is not a monolithic construct nor are women a homogeneous group whereby "current approaches addressing the creation and sustaining of oppressive gender ideologies understand that these not only serve patriarchal interests but also racist, classist and heterosexist ones" (cf. Lane \& Paschyn, 20I8, p. 7).

The predominant postfeminist discourse in the media serves as a commentary on the status of feminism, which appears unnecessary because all gender issues are either already solved in legislation or solutions for them are being suggested, that is, individual elements of feminism have become incorporated in political and institutional life while words such as "empowerment" or "choice" have been converted into an individualistic discourse and are in use by the media and popular culture, as well as institutions serving as a substitution for feminism (McRobbie, 2009).

In accepting the postfeminist values, there is a difference between western and post-socialist countries; while in western countries, the media portrayal of politicians through their feminine characteristics has become mainstream, in post-socialist countries with a pronounced national 
discourse, postfeminism is a complex phenomenon allowing women entry to the public sphere but simultaneously insisting on their femininity and all associated patriarchal stereotypes and cultural mythos (Danova, 2006; Lance \& Paschyn, 2018).

The phenomenon of celebrity feminism, whose media protagonists often speak from their individual perspectives (connected to a feeling of injustice in performing their professional or social roles) pointing out racial, gender or economic hierarchies, sexual violence or other significant social problems, encountered strong criticism from female feminist theoreticians with regard to the professions the celebrities perform, i.e. a deep collision with capitalism in which gender inequality is incontrovertible. Hobson (2016) warns that celebrity feminism is completely opposed to authentic feminism, which is less mainstream and less attractive than the interpretation of feminism offered by show business stars. Hobson emphasises that famous feminist brands are only a stepping stone to true feminism, and at the same time very removed from true feminist ideas because by many standards, primarily their lifestyles, they represent precisely what feminism is trying to bring into question. This is, claims Gay (20I4), "rebranded and reclaimed feminism" advocated not only by beautiful, famous and generally irresistible women but also by male feminists whose word has a "broader reach" and echoing message instantly becomes viral in today's Internet world. Andi Zeisler (2016) claims that celebrity feminists such as Beyoncé, Emma Watson, Taylor Swift and others, who are privileged to publicly speak about inequality and have popularised feminism, are the ones accountable for transforming the unpopular "angry, the cynical and man-hating" (Zeisler, 2016, xii) discourse into a hot marketable topic. Nevertheless, celebrity feminism has great media visibility and cultural capital, especially significant in Internet culture which has made collective conversation and greater democratisation possible. This sort of communication is based on short messages with a limited number of characters, which can hardly be rivalled by the academic discourse (Hobson, 2016).

Empirical research points to women being less represented in the printed media than men (such as Jia at al., 2016; Stanley, 20I2; Harp, Loke \& Bachmann, 20II) and that the same trend has been carried over to digital media. Further research shows that the often seemingly objective reporting on female politicians' activities conceals a deceitful media intention to portray them as depoliticised (Vavrus, 2002; Danova, 2006). Female politicians are written about as "beautiful, elegant women, devoted mothers and wives", and their private appearances and lives are more commented on than their public role (cf. Danova, 2006, p. I3I). 
Studies of gender culture in South-East Europe have shown that the media discourse "mirroring all of the social controversies of transition, as an ideological state apparatus - participates in the reproduction of very retrograde patriarchal ideological matrices" (Moranjak-Bamburać, 2006, p. 3I). Obviously, media are an active manufacturer of intolerance, discrimination and prejudice because one of the important results in multi-ethnic societies is the differentiation of an "ethnically ideal woman" and the "woman as portrayed by the media"; while the former is connected to the ethnic, patriarchal ideology, the other is a "guarantee" of masculinity (Moranjak-Bamburać, 2006).

Researchers dealing with the status of feminism and feminists reveal that from the middle 1990 s we can recognise a negative cognitive framework of feminism (Riley, 200I; Buschman \& Lenart, 1996; Callaghan et al., 1991). The study of Sarah Riley (200I) established the decoupling of feminist values from feminism, in addition to a new sexist discourse which she demonstrated with the example of everyday communication. This decoupling of feminist values from feminism has the purpose of minimising social change connected to gender inequality by using liberal rhetoric in five ways: positioning feminists as extremists; minimising the significance of the historical oppression of women; minimising the privilege of men in history and the present; marginalising the voices calling for change; and decoupling feminism from feminists in order to portray feminist values as gender-neutral.

Feminist demonisation in the media has been confirmed by several studies, among which it is important to point out Rhode (1995) and Lind and Salo (2002) (see Jaworska \& Krishnamurthy, 2012). Rhode discovered that the media uses four strategies while reporting on feminists: "demonisation, trivialisation, polarisation, and the focus on the individual rather than social transformation" (cf. Jaworska \& Krishnamurthy, 2012, p. 404). Demonisation is a strategy focusing on feminists linked to radicalism, unsexed characteristics, and a deviant lifestyle. Emphasis on the physical appearance of feminists serves to trivialise the feminists' efforts. Feminists are also antagonistic, polemical and do not fall into the concept of normal women, which is strategy of polarisation. Among other things, this approach, states Rhode, prevents feminist efforts for collective action. Lind and Salo (2002) have come to similar conclusions; feminists are demonised, feminism is primarily a topic within the media framework of arts and politics while women are generally written about in the private sphere. Authors have concluded that feminism is not seen as essential when it comes to solving women's everyday lives (Jaworska \& Krishnamurthy, 2012). In their comprehensive and significant quantitative 
study conducted on large samples of British and German printed materials, Jaworska and Krishnamurthy (2012) conclude that there is a tendency of the feminist movement holding a negative connotation, which is chiefly connected with attributes such as past, obsolete and irrelevant.

\section{Methodology}

The research was conducted on all articles published in 2019 tagged under "feminism" on the five most visited Croatian Internet portals according to the Gemius Audience report:I 24 sata, Dnevnik.hr, RTL.hr, Večernji list.hr and Net.hr. The number of articles collected by this method was $\mathrm{N}=$ I8. Most articles were published by the portal Dnevnik.hr (7), followed by Večernji list.hr (6), Net.hr (2), RTL.hr (2) and 24 sata.hr (I).

The sample articles were recorded, saved and analysed using NVivor 2 software. The data were processed using qualitative analysis, namely thematic analysis using the "six-phase framework" first suggested for thematic analysis by Braun and Clarke (2006) and Clarke and Braun (2013).

The first step of the analysis was initial coding in order to group the content and determine the themes. Text coding was done by a single person - the author of this paper. The number of texts included in the analysis is relatively small and, even though there was some concern that there would be an overlapping of themes (Maguire \& Delahunt, 2017, p. 3356) and inadequate diversification in approaching feminist themes and subthemes, in my opinion, this did not occur during the data analysis, probably due to the different editorial concepts of the analysed portals.

Since Braun and Clarke (2006) distinguish between semantic and latent analysis, we chose the latent approach, which tries to reveal ideas, assumptions and conceptualisations, i.e. to provide deeper analytical insights. This latent analysis was conducted in line with an established theoretical framework that Braun and Clarke call a top-down theoretical thematic analysis (2006, p. 83) and which dictated the formulation of our research questions:

Question I: What kind of content is tagged as "feminism" on the most visited web portals?

Question 2: Can different interpretations of "feminist" and feminism be identified in the media's approach to themes?

Following the identification of themes, in this case, different approaches to feminism, in order to gain an insight into the latent data structure, we constructed a thematic map providing an interpretative framework on who is the main actor in feminism; what kind of feminist 
activities are reported on; how is feminist activity connotated (positive, negative, neutral); in what time is feminist activity taking place (present, past, future); what kind of hierarchal power relationship is present; is there any mention of the social consequences of those feminist activities and does the text explicitly use the word "feminism" or are the feminist activities described without a direct feminist attribute.

\section{Results and Discussion}

The topic of feminism is generally underrepresented in tags. Namely, on the five most visited web portals in 2019, there were only 17 cases when content was tagged as feminist. Even more, two of the articles described a single event, while the other articles were about different content. Even a sample this small revealed that some of the web portals are more dedicated to feminist topics and others less. Definitely standing out is the portal Dnevnik.hr (namely its subsidiary portal "zadovoljna.hr"), which primarily addresses a female audience. The underrepresentation of feminist themes is consistent with findings on the poor representation of gender and gender policies in the media and their stronger focus on ethnic, regional and religious equality, as well as complete tabloidisation which is present in individual former Yugoslav countries (Croatia, Bosnia and Herzegovina, Serbia) (Isanović, 2006). Also, content featuring women as principal actors is mostly presented as fun and funny content while serious content is generally connected with male actors (Milivojević, 2004, according to Isanović, 2006).

The answer to our first research question "What kind of content is tagged as "feminism" on the most visited web portals?" shows that despite the small number of "feminist" articles there are, at the same time, several different themes through which feminism is covered. Initially, the data suggested a very wide spectrum of topics: from body perspectives and female physical appearance to sex appeal, activism (in connection with religion, public space and LGBT issues), discrimination of women, patriarchy, racism, marking of significant dates, and the "successful women" phenomena. A more in-depth analysis showed that we can recognise five frameworks for presenting feminist content.

\section{Feminist Pioneers}

This is a historical and, in some ways, educational perspective in approaching feminism because the readers are educated on the significance of individual actors and activities. Actors are persons who stand out in history by some activity which promoted feminist-related values or by fighting for the rights of women; for example, Billie Jean King (the tennis player) or 
Amelia Earhart (the pilot). These women are pioneers in their professions and achieved exceptional feats in their lives.

The name Billie Jean King is written in history in gold letters. With I29 tournament wins in her career, which includes 39 Grand Slam titles, this legendary American is one of the most successful female tennis players of all time. (FP-I)

Amelia Earhart is the most famous female pilot of all time... the first woman to fly over the Atlantic and to attempt to fly around the globe. $(F P-2)$

The main actors are women and the topic is their success fighting either men or patriarchal norms and how they became synonyms of female empowerment, which is the focus of this feminist theme.

The 55-year-old Riggs challenged Billie to a duel in an effort to prove that female tennis players are inferior to men. He claimed that no woman is strong enough to beat him... To the general amazement of the men and delight of the women, Billie outright defeated Riggs in a tennis match played according to tennis rules for men. $(F P-I)$

The theme is covered from the position of merging the private and public lives of the actors, with an emphasis on the individual hierarchical power relations typical of patriarchy and traditional societies and closely connected with the public and private lives of both women.

Billie was the first prominent sportswoman in history to publicly declare herself a lesbian... The famous tennis player decided to stop hiding her sexual orientation. At that point in history, the truth could have severely damaged her career and family relations. $(F P-I)$

I wanted to come out even sooner, but my parents were homophobic. And besides, people kept telling me that it would mean the end of women's professional tennis. $(F P-I)$

The title of one of the articles makes an unclear and sensationalist reference to feminist content in order to mask an educational item on the feminist successes of individual women. Namely, the hierarchical position of women is emphasised in the title "Women should stay in the bedroom", which evokes the dominant message given to women at that time. Yet is also serves to grab the attention of modern-day readers because it suggests that the article is about female sexuality and their affiliation with the "bedroom", whereby more naive readers are tricked into reading an educational-feminist article. Alongside the topics of patriarchy and traditional values, the problem of women entering male professions also stands out. 
It is interesting that she had already noticed the division in society when professions are concerned, so she was very excited when in the newspapers she would find articles on successful women who excelled in areas that were considered "male-only". She would cut them out and collect them in her notebook. ( $F P-2$ )

The social consequences of the actors' feminist activities are clearly noted; successful entry into male-only professions, LGBT rights activism in the case of Billie Jean King, and the fact that the Croatian pilot Katarina Matanović saw Amelia Earhart as her female role-model in a profession that remains predominantly male even today.

In the end, she became an ardent $L G B T$ rights activist, all the while advocating women's rights with the same passion. She struck a blow to chauvinism which it has never recovered from. $(F P-I)$

Ultimately, she inspired the first Croatian female pilot Katarina Matanovic Kulenovic, who is, in turn, today celebrated in a series of children's picture books such as "Goodnight stories for young girl rebels". ( $F P-2)$

In this sort of approach to presenting media content, the words feminism and feminist are explicitly mentioned in the text.

The renowned New York Times wrote that she did more for women in that tennis match than most feminists do in their entire lives. $(F P-I)$

Even if the real truth about her fate never comes out, there is no doubt that Amelia is a true hero and feminist role model to women around the world. $(F P-2)$

The educational approach affirmatively covers the topic, and covering topics according to discourse belongs to the second-wave of liberal feminism because the topic is approached in a way which does not connect women to the home or family sphere (Lončarević, 201I) but through speaking about their public activity, clearly stressing gender hierarchy, pointing out discrimination and saying how necessary is individualism and the public activity of women in fighting for their rights.

\section{Female Politicians and Feminism}

The framework of writing on the relationship of feminism and female politicians, unlike educational feminism, does not contain almost anything explicitly feminist. Instead, the activities of female politicians are approached from the level of news stories on their daily or commemorative activities which are apparently considered "feminist" enough themselves. It should be pointed out that only one of the collected articles deals with the relationship between politicians and feminism. 
The actor in this framework is the highest politically positioned woman in 2019, the then President of the Republic of Croatia, who before becoming president was a member of the Croatian Democratic Union, a right-wing nationalist party. This framework never underlines what actually constitutes an activity connected to feminism, except for stressing the Fulbright Lifetime Achievement Award the President received for "her remarkable, contributions as a leader, diplomat, and public servant" which is also omitted from the text, as it only mentions how the President was a Fulbright scholar in the early 2000 s when she studied in the USA. Viewed politically, the only thing standing out is her presiding over the Council of Women World Leaders, which is also not mentioned further in the text.

The activities detailed in the text are primarily of a ceremonial or commemorative nature, with a special emphasis on the award being dedicated to the President's "family and homeland", which stresses the emotional and national charge of her statement.

\section{"I'm proud to dedicate this award tonight to my family and my homeland", stated Grabar Kitarovic, a onetime Fulbrightscholar. (FPO-I)}

The emancipatory potential of writing about feminism is reflected in presenting the actor's personal stance, which basically deals with the wider issue of human rights.

\section{Her experience during the scholarship taught her not to fall prey to prejudice and to keep an open mind to new ideas and new cultures. (FPO-I)}

In the conclusion of the article are the words of the politician which finally point to the problem of gender equality, even though there is no mention of patriarchal power relations. They stress that women "are more than victims", so even though the text deals with the present time, the future dimension is hinted at in the vague vision of women as future agents of crucial social changes, which may be interpreted as a kind of evaluation of the vast female potential for social change.

Women are still unequal. Even though we have achieved a lot, the discrimination and abuse of women and girls, as well as denying their rights, remain widespread. This concerns all women, regardless of their background, their age or position in society. But don't view women as only victims... they are a source of strength and change. $(F P O-I)$

From the distribution of social power viewpoint, this framework explicitly mentions gender but still in vague terms given the practice of not

2 Retrieved August 24, 2020, from https:/vijesti.hrt.hr/553512/nagrada-fulbright-kolindi-grabar-kitarovic 
mentioning the problem. The text headline gives no hint of dealing with the fight for women's rights but accentuates the President's statement that she was "a girl on the wrong side of the Iron Curtain", although it is well known that former Yugoslavia never was one of the countries behind the Iron Curtain. This was very broadly discussed in the media, along with comments that she had used a completely inaccurate comparison.

The text also mentions "discrimination and abuse of women and girls, as well as denying their rights", allowing it to be said that feminist values in this framework are being presented in a positive context, or at least mentioned as a problem. The word "feminism" is never explicitly mentioned in the text. It is necessary to note that the former, right-wing president has never publicly declared herself a feminist, on the contrary, she explicitly refused to do so in an interview (Brakus, 2015) so we can conclude that tagging this approach as "feminism" is the result of an editorial or wider interpretation of feminism-supportive statements.

\section{Celebrity Feminism}

The typical actor of celebrity feminism is a star of celebrity culture, most often connected to the media or pop culture, i.e. the world of show business (film, television shows, music etc.). They advocate feminist values in their public activities and often, because of this, their other actions are interpreted through the framework of feminist values. In this framework, we find Meghan Markle, the former American actress who is now the Duchess of Sussex and wife of Prince Harry as well as Emily Ratajkowski, who is a "model, actress and businesswoman" and reportedly "one of the sexiest women in the world". They are the topic of most articles in our sample $(\mathrm{N}=4)$.

This theme focuses on the physical appearance of the actors, for example "she wore her hair naturally curly, and her freckles back then were more pronounced than they are today" or "she posed with unshaven armpits". Special focus is also placed on sexuality because "women are often ashamed of their sexuality". The importance of "personal choice" and individuality is stressed, not only in relation to one's body but also in relation to behaviour patterns and clothing choices. Although it might seem that these choices are trivial and have no bearing the political and social core of feminism, this thematic focus is typically postfeminist.

I'm aware that my impression of what it means to be a woman when I was young was mostly influenced by misogynistic culture. Even more, I'm convinced that it still affects my views on sex appeal. But I don't mind it because that is something I chose myself. Isn't that the essence of feminism - the right to choose? (CF-I) 
Physical attractiveness and charm are pointed out as crucial in achieving success which is portrayed as the seduction of a prince and entering the royal family, as is the case with Meghan Markle.

Her beauty and charm seduced even Prince Harry and she managed to get all the way to the Buckingham Palace. $(\mathrm{CF}-2)$

This thematic framework is not deprived of emphasising the actors' awareness of gender hierarchy and inherent discrimination; on the contrary, it strongly accentuates feminist awareness and activism.

Nine-year-old Meghan participated in the "Nick News" show in 19go, protesting against sexist commercials... Meghan was included after having written a protest letter explaining that it is wrong for the show to be called an educational programme if they're promoting sexism in their commercials. (CF-I)

When I was arrested in Washington during the protest against the Supreme Court nomination of Brett Kavanaugh, a man who spent his life disrespecting women, the new headlines weren't about the protest but about the shirt I was wearing. Even left-wing female commentators, who completely supported my reasons for protesting, were commenting on how I managed to forget to wear a bra under the white shirt I wore with my jeans. ( $C F-2)$

Social implications of feminist values are well mirrored by Ratajkowski's statement: "Give women the opportunity to be whatever they want and learn to accept the differences. Preconceptions be damned!"; because its message is clearly that female power can be expressed and strengthened even through one's relationship with their body. At the core of that relationship, obviously, are individuality and the feeling of personal empowerment.

If I decide to shave my armpits or grow them out, that's up to me. For me, body hair is another opportunity for women to exercise their ability to choose - a choice based on how they want to feel. $(\mathrm{CF}-2)$

However, accepting this kind of feminist exposure did not result in a wider understanding of the readers because the social network comments were mostly focused on the hygiene aspects of women's relationship with their bodies, which derogated Ratajkowski's actions and intentions to the level of triviality.

The comments mostly focused on the photograph published with the essay, which featured Emily Ratajkowski with unshaven armpits. (CF-2)

This thematic framework also superficially stresses the class dimension of the Meghan Markle case: "She grew up in a completely normal 
family in California, her parents were divorced and the lived in average American circumstances". The rapid success following her getting married did not affect her feminist values:

She still talks about the same things, cares about the same issues and tries to promote feminism in every way possible. She was always the girl for change and by marrying she found the ideal platform to continue loudly telling the world what she really thinks. (CF-I)

In this framework, the word feminism is explicitly mentioned. The text's temporal dimension is such that it almost completely deals with the present, that is, the past is mentioned only in connection with the continuity of expressing feminist attitudes. Feminism is discussed affirmatively; it is almost presented as mainstream, something immanent and normal for every woman. It is suggested that the advocates of feminism are bold and self-conscious women.

\section{Feminist Activism}

The theme of feminist activism, unlike other thematic frameworks, presents feminism through much more serious and complex stories, regardless of whether they come from the area of social activism, academic community or culture.

The actors of this thematic framework are women such as Seyran Ates, feminist, human rights activist and a female imam who founded a mosque and says she is fighting against political Islam and patriarchy. Another is the sociologist Sara R. Farris, who wrote the book In the Name of Women's Rights: The Rise of Femonationalism dealing with orientalist theories and theories of gender, race and social reproduction, particularly as they apply to the analysis of migrant women in Europe. Another article featured the news that the activist, actress and producer Jelena Veljača, who had co-organised the "Justice for little girls" protest demanding a system of helping victims of sexual abuse, was a guest on Croatian television. She had commented on the \#MeToo movement and argued with the TV host about the relationship of the producer Harvey Weinstein and actress Salma Hayek after the actress had published a column in The New York Times in which she broke a I 4-year silence and spoke about the nature of Weinstein's sexual demands she had experienced while they were working together.

Under actors, I included feminist authorships or cult achievements such as, for example, the Vienna premiere of an opera composed and directed by women featuring a libretto based on the biographical novel by Virginia Woolf Orlando: A Biography because the said novel questions 
gender norms and is considered one of the first English novels about transgender issues. The title clearly highlights that the opera's title role is played by a transgender person. Here I also included the play I haven't stopped since the morning by the Croatian drama writer Una Vizek, which speaks about the power relations between men and women in the private sphere because in the imaginary matriarchal society women hold all the power, while the men are at home, taking care of the children, doing the laundry and cooking... they haven't stopped since morning.

Given the variety of actors, different hierarchical relationships are mentioned; for example, in the case of the liberal mosque, the issues are gender equality and the acceptance of LGBTIQ identities, the right of women to pray alongside men and asking for the possibility of women to lead in prayer as well as social implications of feminist values.

I've been fighting against so-called political Islam, against patriarchy and traditional structures in my Turkish-Kurdish community since I was Is-years-old - says thisfeminist, whose life was transformed because of her activism. (FA-I)

And while religious freedom is one of the basic human rights, it is not more important than other rights, such as women's rights or sexual rights. And those rights also have to be respected. ( $F A-I)$

This theme further broaches a number of subthemes important to feminism and feminist theory; for example, the literary work of Virginia Woolf touches upon the issue of identity: the novel ... written in a satirical biographical manner, she dedicated to her female lover and long-time friend Vita Sackville-West, an eccentric British poetess. Another theme which was introduced is that of racism, i.e. the reinforcement of nationalist strategies which blame the disempowerment of European workers on migrants and which also serve to strengthen the right-wing options. Further, the subtheme of femonationalism was mentioned, in the sense of neonationalists and neoliberals exploiting feminist ideas. The noted issues are some of the main contemporary political and feminist questions in the European and global contexts.

Racism definitely plays a role in strengthening the right-wing movement by spreading the idea that all our problems are caused by migrants. This is a classic rightwing nationaliststrategy. $(F A-2)$

I view femonationalism as an integral part of the neoliberal reorganisation of the social, labour and state immigration policies within the context of the mentioned financial crisis. It is also an attempt by west European parties to advance their xenophobic politics by advocating for gender equality. It is actually fascinating 
that those parties are using the ideas of women's rights in an effort to lobby against migrants and Muslims. On the other hand, an increasing number of these parties are led by women, for example, Marine Le Pen, which makes them additionally attractive to other women. (FA-2)

You are a white heterosexual male in a position of power. You do not understand that men and women, even when they occupy the same position of power, are not equal. This is what feminism is trying to say for a long time now. ( $F A-3)$

One of the hierarchal relationships being indicated is the one involving individual European feminists (Élisabeth Badinter, Ayaan Hirsi Ali, Oriana Fallaci) joining anti-Islam movements. This is also the only thematic framework dealing with the activist engagement of other feminists and the only one which notes a distinction between feminist activist orientations.

Entire female organisations have turned ... against Muslims by advocating a ban on wearing traditional coverings and portraying Muslim women as passive victims which need to be rescued and emancipated. This anti-Islam feminist front presents sexism as a sole component of Muslim culture and Islam as a dangerous religion which must be stopped. (FA-2)

During the 6os and 7os, there were ideological divisions between Marxist and radical feminists, but at the same time, they all agreed on issues of abortion rights, employment and divorce. All those women came from completely different backgrounds but they were united in their demands. Today feminism remains very divided, especially based on class. $(F A-3)$

This thematic framework speaks affirmatively of feminism and also discusses the status of academic feminism, providing greater insight into the more complex division of feminism, as well as the issue of women accepting male values and positions in corporations.

The so-called academic feminism is a powerful phenomenon dating from the Iggos and early 2000s which has been gaining popularity in the past ten years among younger women and at a global level. The young are especially drawn to the neoliberal feminism... The women of today want to be louder, more visible and successful, and to have more self-confidence. $(F A-3)$

The term feminism is not mentioned in all the articles; for example, it is not referenced in the article about the opera portrayal, but is clearly articulated in all of the other articles. This thematic framework is focused on the present, featuring topics which are significant to diverse contemporary societies. 


\title{
Feminism and Film
}

This thematic framework comments on feminist-themed movies as well as their main protagonists or announces specialised events such as feminist film festivals. Generally, it features film critiques or articles inspired by the feminist actions of movie protagonists. One of them showers such praise on the movie "Legally Blonde" that it even suggests a kind of "feminist know-how" or "guide to life" for young girls which is based on the movie script. Namely, the actors of this thematic framework are movie characters, such as Elle Woods for example.

In the comments of movie portrayals, the hierarchical aspects, i.e. power relations, are relatively emphasised through the retelling of the movie plot.

\section{When she first arrived at Harvard, Elle Woods was seen by everyone as a stereo- typical stupid blonde and made fun of because of her clothing style. (FF-I) \\ One of the landmark scenes in the movie "Legally Blonde" is certainly the one in which professor Callahan invites Elle to his office pretending to want to congratu- late her. He then proceeds to try and convince her to sleep with him if she wants to advance her career. $(F F-I)$}

In the desire for feminist achievements of the movie hero Elle Woods to be transferred into a personal, real-life philosophy, this framework offers numerous pearls of wisdom inspired by the feminist actions of this film character presented as advice, so it can be said that the implications of potentially "feminist activity" are extremely pronounced. The text is primarily entertaining in character and is evidently intended for younger readers.

\author{
If something feels weird, it means it is weird. \\ ... nobody should suffer sexual harassment to succeed. \\ Don't be afraid to take the lead. \\ ... Elle is persistent enough and confident enough to take the lead. \\ Always be the best friend you can be. \\ ... Elle always makes sure that her friends are ok before she even looks at a man... \\ she is the president of her sorority. (FF-I)
}

The word feminism is mostly omitted from this thematic framework and when it is used for the purpose of analysis it is mostly in compound terms such as "the film's feminist framework". In one of the examples, this is elaborated through a string of cultural stereotypes denoting that women are not perceived as carriers of power unless they behave or appear in accordance with codes of hegemonic masculinity. About the example of 
the movie "Terminator: Dark fate", under the title "The irrelevant new Terminator movie: light action for kids with no thrill, fear or mystery but with an unconvincing feminist twist", the following is written:

\section{This type offeminist twist might have worked in the superb last instalment of Mad Max: Fury Road (2015), but it doesn't work here. Even the old grey-haired Sarah can hardly convince anyone that she could endure even Io seconds against the new terminator, much less that she's capable of destroying it like some fierce warrior. $(F F-2)$}

In this thematic framework, the feminist values are contextualised in two ways - affirmatively, as we have already stated, and negatively, like in the following example:

Finally, it all seems like an unconvincing attempt to glorify the vision of gynecocra$c y$, a society where all the power is held by women. $(F F-2)$

\section{Conclusion}

The positioning of feminism on the bulletins of web portals can, from an educational standpoint, seem confusing because on one hand social institutions are increasingly incorporating gender awareness and taking gender parity into account while, on the other, the topic of feminism is sooner marginalised and trivialised than represented, in line with previous scientific knowledge (McRobbie, 2009; Lind \& Salo, 2002; Rhode, 1995; Jaworska \& Krishnamurthy, 2012).

We determined that the articles on feminism fit into one of five thematic frameworks: feminist pioneers, female politicians and feminism, feminist activism, celebrity feminism, and feminism and film. The feminist activism framework holds the greatest educational potential because it mostly presents interviews or statements by feminists of an academic, cultural or activist provenance who are also the main actors of this framework and whose statements authentically broach a series of feminist subthemes ranging from the relationship towards sexual violence, family violence, patriarchal values, LGBT rights, racial rights, migrants etc. Due to the gravity of the approach to the subject, this framework is also the least attractive in terms of following feminism for an audience desiring concise and short messages (Hobson, 2016) but it is also the only framework touching on the ideas of "real feminism" (Gay, 2014). The feminist pioneers thematic framework is oriented to the past and also features an educational intent by introducing the audience to women who have managed to succeed in male-dominated professions. This framework is more built on the idea "see what women can accomplish" than on the ideas of 
feminism, although feminism is mentioned in the framework as well as the public activism of individual actors. The actors of this framework are written about both from the public and the private sphere, sometimes garnished by lascivious headlines.

The thematic framework female politicians and feminism is surprisingly the least educational; namely, there is almost no mention of politics, feminism as a word is not mentioned and the framework does not feature any true political feminist messages. This result is surprising but corresponds to the earlier mentioned theoretical insights of McRobbie (2009) that there is a new form of sexual contract in action because the political framework basically speaks about the educational achievements of the highest-ranking female politician; sending a laconic message to women that education brings equality so that educated women can realise their highest ambitions, including ambitions in high politics.

Certainly, most attractive to young audiences are the thematic frameworks celebrity feminism and feminism and film which are built on famous real or fictional actors. While the former are attractive due to their popularity in show business and their lifestyles, the latter are known to younger audiences from high-budget movies. Celebrity feminism definitely is very significant in spreading feminist values because it broaches an array of important and contemporary themes like female bodies, sexism etc. But at the same time a series of themes crucial for the global or local context such as abortion, reproductive rights etc. does not feature in this framework (Bachmann et al., 2018) nor does it speak about actual marginalised women (Vavrus, 2002). The feminism and film framework is more entertaining in character and features comments upon movies or (non)feminist acts of movie characters. Some of the individual comments in this framework are stereotypical in nature so it remains questionable how much the authors actually understand feminism and from which position their comments are coming.

Despite the limitations of this analysis due to the small sample, we can say that how useful the Internet is for feminism and how feminism is truly perceived by young audiences should be studied by asking them directly. However, it is certain that the entertaining and simplified messages hinting at feminism sent by celebrity feminists will resonate most strongly with young people.

\section{References}

Albertson, W. C. (2018). Sleeping with the Enemy: The Male Gaze and Same-Sex Relationships on Broadcast Network Television. In D. Harp, 


\section{J. Loke, \& I. Bachmann (Eds.), Feminist Approaches to Media Theory} and Research (pp. 53-64). Palgrave Macmillan.

Brakus, A. (2015). Seksizam, mizoginija i bijeg od feminiz-

ma. Na svu sreću, KGK izjavila je kako nije feministkin-

ja. Retrieved July 7, 2020, from https://www.libela.org/

sa-stavom/6338-na-svu-srecu-kgk-izjavila-je-kako-nije-feministkinja/.

Bachmann, I., Harp, D., \& Loke, J. (2018). Through a Feminist

Kaleidoscope: Critiquing Media, Power, and Gender Inequalities. In

D. Harp, J. Loke \& I. Bachmann (Eds.), Feminist Approaches to Media Theory and Research (pp. I-16). Palgrave Macmillan.

Braun, V., \& Clarke, V. (2006). Using thematic analysis in psychology. Qualitative Research in Psychology, 3(2), 77-101.

Buschman, J. K., \& Lenart, S. (1996). “I am not a feminist, but...”: College women, feminism, and negative experiences. Political Psychology, I7(I), 59-75.

Byerly, C. M., \& Ross, K. (2006). Women and Media: A Critical Introduction. Blackwell.

Callaghan, M., Cranmer, C., Rowan, M., Siann, G., \& Wilson, F. (1999). Feminism in Scotland: Self-identification and stereotypes. Gender and Education, $I I(2)$, I6I-I77.

Clarke, V., \& Braun, V. (2013). Teaching thematic analysis: Overcoming challenges and developing strategies for effective learning. The Psychologist, 26(2), 120-I23.

Danova, M. (2006). Women in politics in Bulgarian newspapers: post-feminism in a post-totalitarian society. In N. Moranjak-Bamburać (Ed.), Stereotyping: Representation of Women in Print Media in South East Europe (pp. III-I32). Mediacentar.

Gay, R. (2014). Emma Watson? Jennifer Lawrence? These aren't the feminists you're looking for. Retrieved August 8, 2020, from https://www.theguardian.com/commentisfree/2014/ oct/ro/-sp-jennifer-lawrence-emma-watson-feminists-celebrity.

Hall, S. (1988). The Hard Road to Renewal: Thatcherism and the Crisis of the Left. Verso.

Harp, D., Loke, J., \& Bachmann, I. (2016). The spectacle of politics: Wendy Davis, abortion, and pink shoes in the Texas 'fillybuster'. Journal of Gender Studies, 26(2), 227-239.

Hobson, J. (2016). Celebrity Feminism: More Than a Gateway.

Retrieved July 20, 2020, from http://signsjournal.org/ currents-celebrity-feminism/hobson/. 
Isanović, A. (2006). Media discourse as a male domain: Gender representation in the daily newspapers of Bosnia and Herzegovina, Croatia and Serbia. In Stereotyping: Representation of Women in Print Media in South East Europe (pp. 43-80). Mediacentar.

Jaworska, S., \& Krishnamurthy, R. (2012). On the F word: A corpus-based analysis of the media representation of feminism in British and German press discourse, 1990-2009. Discourse and Society, 23(4), 4OI-43I.

Jia S., Lansdall-Welfare T., Sudhahar S., Carter C., \& Cristianini N. (2016). Women Are Seen More than Heard in Online Newspapers. PLoS $O N E, I I(2)$, eOI 48434 .

Lind, R., \& Salo, C. (2002). The Framing of Feminists and Feminism in News and Public Affairs Programs in U.S. Electronic Media. Journal of Communication 52(I), 21 I-228.

Lance, E. A., \& Paschyn, C. (2018). The Applicability of Symbolic Annihilation in the Middle East. In D. Harp, J. Loke \& I. Bachmann (Eds.), Feminist Approaches to Media Theory and Research (pp. 37-52). Palgrave Macmillan.

Lončarević, K. (2OII). Liberalni feminizam u 20. veku. In I. Milojević \& S. Markov (Eds.), Uvod u rodne teorije (pp. I27-138). Univerzitet u Novom Sadu, Centar za rodne studije.

Maguire, M., \& Delahunt, B. (2017). Doing a Thematic Analysis: A Practical, Step-by-Step Guide for Learning and Teaching Scholars. AISHE-J, 8(3), 335I-335I4.

McRobbie, A. (2009). Gender, Culture and Social Change. SAGE.

Moranjak-Bamburać, N. (2006). The unbearable lightness of stereotypes. In N. Moranjak-Bamburać (Ed.), Stereotyping: Representation of Women in Print Media in South East Europe (pp. 9-42). Mediacentar.

Pateman, C. (1988). Spolni ugovor. Ženska infoteka.

Riley, S. (200I). Maintaining Power: Male Constructions of "Feminists" and "Feminist Values". Feminism \& Psychology, II (I), 55-78.

Stanley, J. (2012). Women's Absence from News Photos: The Role of Tabloid Strategies at Elite and Non-elite Newspapers. Media, Culture \& Society, 34, 979-998.

Vavrus, M. D. (2002). Postfeminist News: Political Women in Media Culture. SUNY Press.

Zeisler, A. (2016). We Were Feminists Once: From Riot Grrrl to CoverGirl, the Buying and Selling of a Political Movement. Public Affairs. 
ŠOLSKO POLJE, LETNIK XXXI, ŠTEVILKA 5-6

\section{Web sources}

https://vijesti.hrt.hr/5535I2/nagrada-fulbright-kolindi-grabar-kitarovic (17. 06. 2020) 